\title{
Ocena oddziaływania propelantów na wybrane próbki węgla kamiennego
}

\section{Assessing the impact of propellants on selected hard coal samples}

\author{
Kamil Hebda' ${ }^{1}$ Łukasz Habera ${ }^{1}$, Antoni Frodyma ${ }^{1}$, Piotr Koślik² \\ ${ }^{1}$ Instytut Nafty i Gazu - Państwowy Instytut Badawczy \\ ${ }^{2}$ Instytut Przemysłu Organicznego, Oddział w Krupskim Młynie
}

\begin{abstract}
STRESZCZENIE: Artykuł powstał na podstawie wyników badań szczelinowania gazowego z wykorzystaniem materiałów wysokoenergetycznych (propelantów) na wybranych próbkach węgla kamiennego w laboratoryjnym silniku rakietowym (LSR). Celem badań było sprawdzenie, czy metoda stymulacji przepływu mediów ze złoża do odwiertu naftowego z użyciem propelantów może być skutecznie stosowana przy niekonwencjonalnych nagromadzeniach węglowodorów, jakimi są złoża metanu z pokładów węgla kamiennego (CBM). Szczelinowanie materiałami wysokoenergetycznymi polega na niedetonacyjnym wykonaniu kilku radialnych szczelin w strefie przyodwiertowej o długości do kilku metrów. Szczeliny powstają w wyniku spalania propelantów, które generują duże objętości gazów prochowych pod wysokim ciśnieniem, przez co zostaje przekroczone ciśnienie nadkładu skał w górotworze. Zakres badań obejmował serię prób szczelinowania gazowego wybranych próbek węgla kamiennego na poligonie doświadczalnym. Zabieg szczelinowania wykonano w laboratoryjnym silniku rakietowym, który standardowo służy do badania właściwości stałych paliw wysokoenergetycznych, jednak na potrzeby testów szczelinowania został odpowiednio zmodyfikowany. Próbki węgla wklejono za pomocą żywicy epoksydowej w specjalne stalowe obudowy, dzięki czemu produkty spalania propelantów mogły ingerować w strukturę węgla - szczelinując go. Do badań wykorzystano inhibitowane małogabarytowe paliwo wysokoenergetyczne (MPH) o zmiennej gramaturze. W celu określenia zmian w strukturze węgla próbki przeskanowano tomografem komputerowym przed i po próbach ciśnieniowych. Otrzymane tomogramy zrekonstruowano przy wykorzystaniu specjalistycznego oprogramowania komputerowego na obrazy 3D sieci spękań oraz ich procentową objętość w każdej z badanych próbek. Dodatkowo podczas prób poligonowych rejestrowane było ciśnienie maksymalne w komorze spalania w LSR. Badanie szczelinowania przeprowadzono dla 10 próbek węgla kamiennego, z czego udało się zeszczelinować 7 z nich. Przyrost szczelin w tych próbkach waha się od 9,3\% do 332,5\%. W przypadku 3 próbek zabieg szczelinowania skończył się niepowodzeniem.
\end{abstract}

Słowa kluczowe: metan z pokładów węgla kamiennego, szczelinowanie gazowe, propelanty, tomografia komputerowa.

ABSTRACT: The article is based on the results of gas fracturing with high-energy materials used for selected hard coal samples in a laboratory rocket motor (LRM). The purpose of the research was to check whether the method of stimulating the flow of media from the deposit to the oil well using propellants can be effectively used with unconventional hydrocarbon accumulations such as coalbed methane (CBM). Fracturing with high-energy materials consists in a non-detonative forming of several radial fractures in the near-well bore zone of lengths up to several meters. The fractures are formed as a result of the combustion of propellants which generate large volumes of combustion gases under high pressure, thus exceeding the pressure of overburden rocks. The scope of the research included a series of gas fracturing tests of selected hard coal samples on the testing ground. The carbon samples were glued with special epoxy resin into a special steel pipe, by which the propellant combustion products could affect the coal structure by fracturing. The fracturing treatment was performed in a laboratory rocket motor, which is a standard system for testing the properties of solid high-energy fuels; however, for the purpose of fracturing tests, it has been modified accordingly. The tests were performed with the application of inhibited small-dimension high-energy solid fuel (MPH) with variable weight. In order to determine changes in the coal structure, the samples were scanned with X-ray computed tomography, before and after tests on the testing ground. The obtained tomograms were reconstructed using specialized computer software for 3D images of the fractures system and their percentage volume in each of the coal samples. In addition, during the testing ground tests, the maximum pressure in the combustion chamber in LRM was recorded. The gas fracturing treatments were carried out for 10 hard coal samples, of which 7 were successfully fractured. The growth of fractures in these samples ranged from $9.3 \%$ to $332.5 \%$. For 3 samples, the gas fracturing was unsuccessful.

Key words: Coal Bed Methane, gas fracturing, propellants, X-ray computed tomography.

Autor do korespondencji: K. Hebda, e-mail: kamil.hebda@inig.pl

Artykuł nadesłano do Redakcji: 5.06.2019 r. Zatwierdzono do druku: 05.12.2019 r. 


\section{Wstęp}

Metan z pokładów węgla kamiennego zaliczany jest do niekonwencjonalnych złóż węglowodorów, które wymagają specjalnych metod udostępniania (Poprawa, 2010). Pokłady węgla kamiennego, w których nagromadzone są węglowodory (głownie metan), stanowią dla tego gazu jednocześnie skałę macierzystą i zbiornikową. Skały zbiornikowe, będące węglem kamiennym, charakteryzują się bardzo niską porowatością oraz przepuszczalnością, dlatego aby je eksploatować, należy stosować zabiegi ich stymulacji. Niekonwencjonalne złoża węglowodorów posiadają bardzo duże zasoby (Hadro, 2010). Największe udokumentowane zasoby metanu w pokładach węgla kamiennego w Polsce występują w Górnośląskim Zagłębiu Węglowym (Kwarciński i Hadro, 2008). Złoża na tym obszarze szacowane są na poziomie $250 \mathrm{mld} \mathrm{m}^{3}$. Zasoby bilansowe wynoszą 95 mld $\mathrm{m}^{3}$, w tym z obszarów kopalń $29,8 \mathrm{mld} \mathrm{m}^{3}$ (Krzystolik i Skiba, 2009). Są to ogromne nagromadzenia gazu ziemnego, których bezpieczna i skuteczna eksploatacja przyczyniłaby się do poprawy bezpieczeństwa energetycznego kraju.

Metan w pokładach węgla utrzymywany jest w równowadze poprzez ciśnienie otaczających go wód złożowych zgromadzonych w naturalnym systemie spękań. W celu uwolnienia przepływu metanu wykonuje się zabiegi obniżenia ciśnienia w złożu poprzez odprężenie górotworu, powodowane odwodnieniem pokładów węgla (Hadro i Wójcik, 2013). Po obniżeniu ciśnienia w górotworze do wartości izotermy sorpcji następuje proces uwolnienia metanu z pokładów węgla (proces desorpcji). Ilość uwolnionego gazu określa się za pomocą współczynnika odgazowania (Gonet et al., 2010). Ze względu na to, że węgiel posiada bardzo niską przepuszczalność, przypływ metanu w wyniku obniżenia ciśnienia za pomocą odwodnienia pokładów jest niewielki. Dlatego w celu intensyfikacji wydobycia stosuje się specjalne metody eksploatacji: wykonuje się odwierty konwencjonalne z powierzchni, z perforacją oraz ze szczelinowaniem hydraulicznym. Najpopularniejszą metodą udostępniania pokładów węgla w Stanach Zjednoczonych jest wiercenie otworów horyzontalnych ze szczelinowaniem hydraulicznym. Metoda ta w polskich warunkach jest trudna do realizacji ze względu na skomplikowaną budowę geologiczną złóż węgla kamiennego.

Alternatywną metodą dla szczelinowania hydraulicznego może być szczelinowanie gazowe materiałami wysokoenergetycznymi, które jest znacznie tańsze i nie wymaga zaangażowania dużej ilości sprzętu, przez co ten zabieg może być wykonany z wybranego pokładu w kopalni węgla kamiennego. Wytworzone w wyniku szczelinowania gazowego spękania mają do kilku metrów długości. Powstanie spękań uwarunkowane jest szybkością narastania ciśnienia. Zabieg trwa kilkadziesiąt milisekund, a największe wartości ciśnienia przewyższają naprężenia maksymalne górotworu, wynoszące maksymalną wartość ciśnienia nadkładu skał. Uważa się, że szczeliny powstałe w wyniku szczelinowania gazowego samoczynnie zapobiegają zamykaniu się w wyniku działania dyslokacji ścinającej (Habera et al., 2014).

Zabiegi szczelinowania gazowego wykonywane są pod przybitką cieczy - ciśnienie, jakie wytwarza woda działająca na układ szczelinujący koncentruje ciśnienie gazów prochowych na ściankach otworu. Dodatkowo ciecz skutecznie obniża temperaturę spalającego się propelantu (Habera et al., 2019).

Do tej pory badania na węglach wykonywano dla małej populacji próbek i nie udało się określić przyrostu liczby spękań w skałach w zależności od gramatury propelantu lub maksymalnej wartości ciśnienia w układzie badawczym (Hebda et al., 2018a, 2018b, 2019). Dlatego w przedstawianych badaniach zwiększono liczbę próbek węgla, a wyniki badań zostały poddane analizie określającej zależność pomiędzy ilością powstałych szczelin w węglach oraz ciśnieniem maksymalnym w układzie badawczym.

\section{Metoda badawcza}

Celem prac było sprawdzenie skuteczności szczelinowania gazowego z wykorzystaniem materiałów wysokoenergetycznych na próbkach węgla kamiennego. Testy strzałowe wykonano dla 10 wybranych próbek węgla.

Badania na węglach wykonano na poligonie doświadczalnym należącym do Instytutu Przemysłu Organicznego, oddział w Krupskim Młynie. Zabieg szczelinowania był realizowany w komorze laboratoryjnego silnika rakietowego (LSR), który odpowiednio zmodyfikowano - dyszę zastąpiono walcem węglowym oraz usunięto kanał wylotowy (rys. 1). Dodatkowo w komorze spalania w LSR znajdował się czujnik ciśnienia $100 \mathrm{MPa}$ (PCB M102B06), który rejestrował ciśnienie maksymalne w układzie badawczym podczas każdej z prób szczelinowania.

Na potrzeby badań z większych brył węgla kamiennego wyrdzeniowano walce o długości i średnicy $5 \mathrm{~cm}$ oraz w każdym z nich nawiercono kanał o długości $2 \mathrm{~cm}$, imitujący perforację, który ukierunkował oddziaływanie produktów spalania propelantów (ciśnienia i temperatury) na skałę. Następnie próbki węgla przeskanowano tomografem komputerowym i za pomocą specjalistycznego oprogramowania wykonano rekonstrukcję uzyskanych tomogramów w celu określenia pierwotnej liczby spękań w każdym z walców węglowych (objętości istniejących spękań do objętości całej próbki węgla). Następnie próbki wklejono za pomocą żywicy epoksydowej w specjalne stalowe obudowy umożliwiające szczelinowanie skał w LSR. 


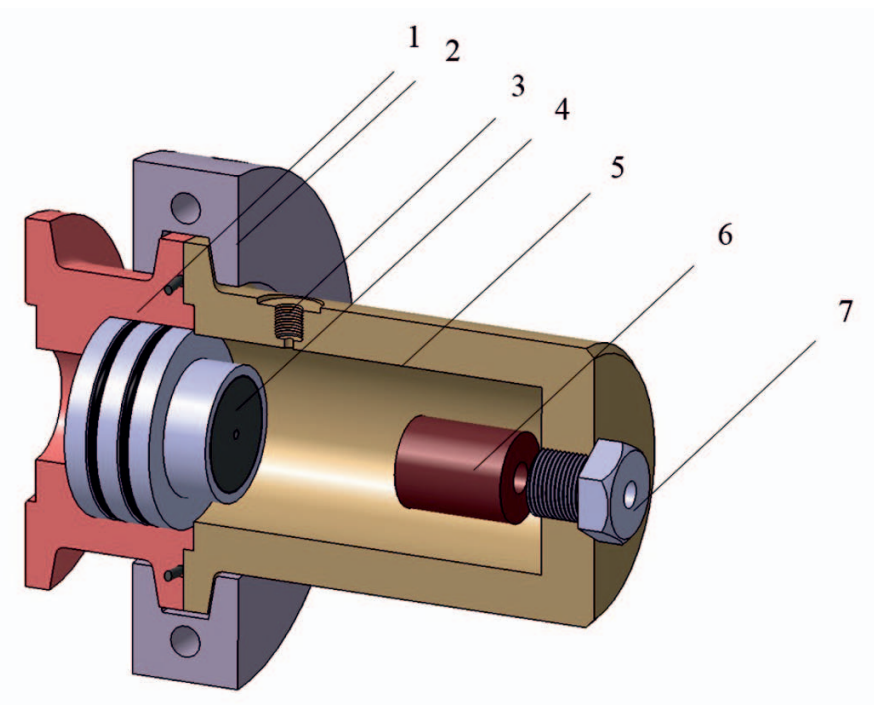

Rys. 1. Model laboratoryjnego silnika rakietowego wykorzystywany do badań szczelinowania gazowego na próbkach węgla kamiennego; 1 - dysza wylotowa, 2 - obejma łącząca elementy LSR, 3 - gniazdo na czujnik ciśnienia, 4 - obudowa na węgiel, 5 - komora spalania, 6 - propelant, 7 - główka zapalcza ze środkiem inicjującym

Fig. 1. A model of the laboratory rocket motor used for gas fracturing on hard coal samples. 1 - nozzle, 2 - clamp connecting LRM elements, 3 - coal casing, 4 - pressure sensor, 5 - combustion chamber, 6 - propellant, 7 - ignition head with initiating agent

Zabieg szczelinowania gazowego odbywał się w komorze spalania laboratoryjnego silnika rakietowego. W układzie badawczym z jednej strony znajdował się inicjator wraz z paliwem wysokoenergetycznym, na wprost umieszczony był walec węglowy w stalowej obudowie. Komora silnika została uszczelniona, aby gazy prochowe oddziaływały bezpośrednio na skałę (rys. 2). Paliwo, które zostało wykorzystane do badań, to inhibitowane małogabarytowe paliwo wysokoenergetyczne (MPH). Paliwo zostało zainicjowane masą pirotechniczną umieszczoną w główce zapalczej. Próby poligonowe przeprowadzono z zastosowaniem paliwa o różnej gramaturze.
Po badaniach na poligonie doświadczalnym próbki węgla kamiennego najpierw były poddawane ocenie makroskopowej, a następnie zostały ponownie przeskanowane tomografem komputerowym, uzyskane tomogramy poddano rekonstrukcji. Na tej podstawie określono wtórną sieć spękań powstałych po szczelinowaniu gazowym. Następnie oszacowano procentowo przyrost spękań w każdej z próbek węgla.

Dodatkowo na podstawie rejestracji z czujnika uzyskano ciśnienie maksymalne w komorze spalania w LSR.

\section{Wyniki badań}

Na podstawie obserwacji makroskopowych stwierdzono, że ciśnienie produktów spalania propelantów w próbkach od 1 do 7 wpłynęło na strukturę węgla kamiennego - zaobserwowano powstanie szczelin. W próbkach nr 8, 9 i 10 ze względu na niedoskonałości w próbkach węgla produkty spalania materiałów wysokoenergetycznych propagowały pomiędzy krawędzią próbki a obudową. Wszystkie próbki zostały nadpalone w wyniku spalania propelantów (rys. 3).

Następnie w wyniku rekonstrukcji tomogramów zobrazowano przebieg szczelin w każdej z próbek węgla kamiennego oraz określono liczbowo ich objętość w skale. W próbkach nr 8, 9 i 10 potwierdzono niepowodzenie próby szczelinowania skał w LSR. W pozostałych próbkach zabieg szczelinowania gazowego powiódł się, powodując przyrost liczby szczelin.

Analizując kształt powstałych spękań, zaobserwowano, że ciśnienie gazów prochowych początkowo szczelinowało próbkę nawierconym kanałem imitującym perforację, następnie propagowało istniejącą w próbce siecią spękań pierwotnych, będącą punktami osłabienia skały, po czym wydmuchiwało fragmenty skały z układu. W wyniku szczelinowania nie powstały modelowe szczeliny tworzące się $\mathrm{w}$ tego typu zabiegach - kształt powstałych szczelin przypomina kanały (rys. 4).
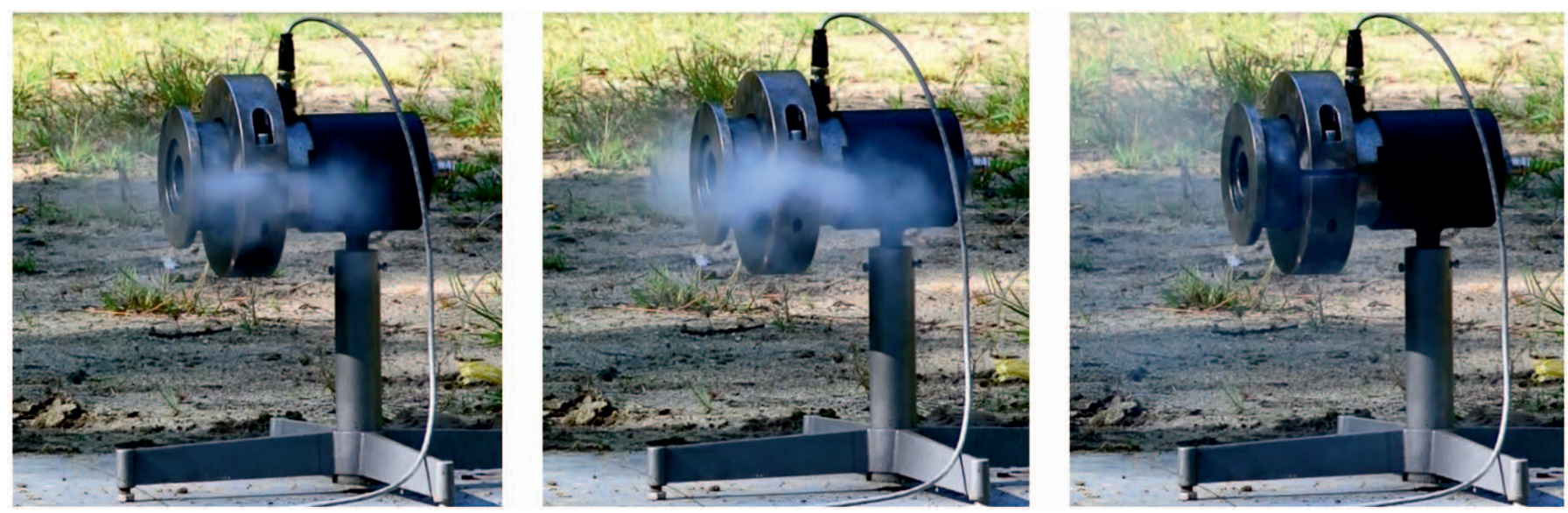

Rys. 2. Sekwencja zdjęć przedstawiająca jedną z prób szczelinowania gazowego węgli z wykorzystaniem propelantów

Fig 2. A sequence of photos showing one of the attempts at gas fracturing of hard coals using propellants 

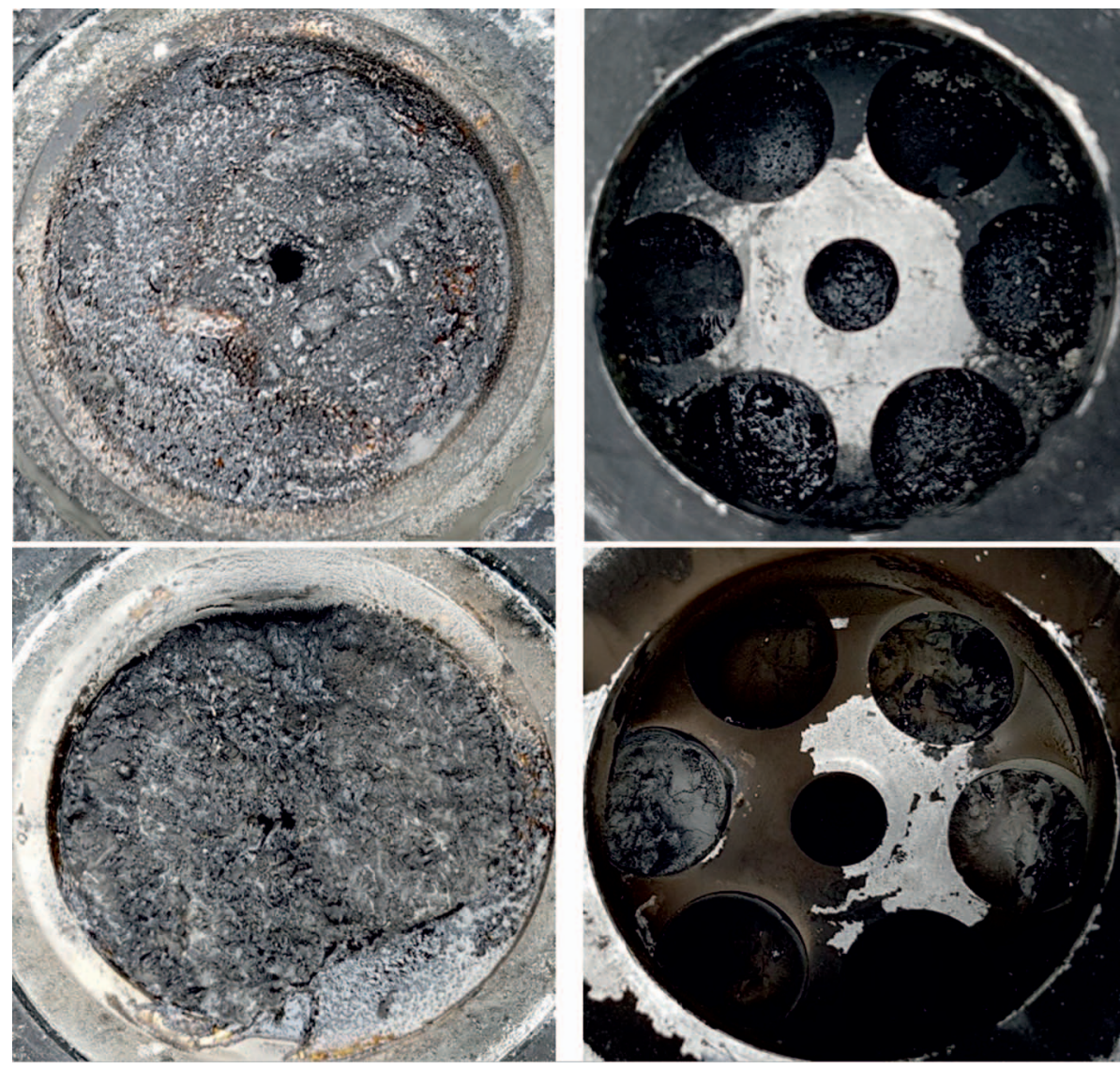

Rys. 3. Górny rząd przedstawia udaną próbę szczelinowania gazowego próbki $\mathrm{nr} 3$. Na powierzchni próbki, gdzie gazy prochowe wylatywały z układu badawczego, widoczna jest makroskopowo sieć spękań o małym rozwarciu. W dolnym rzędzie przedstawiono nieudaną próbę szczelinowania próbki nr 5, gdzie ciśnienie w wyniku niedoskonałości próbki węgla nie propagowało na-

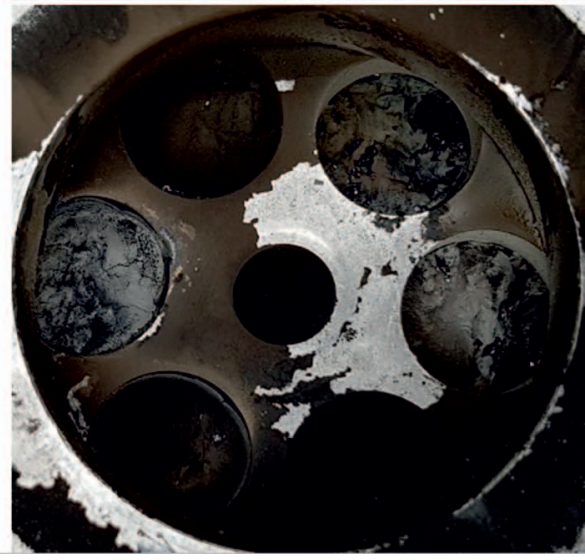
wierconym kanałem imitującym perforację, a krawędzią pomiędzy próbką a obudową

Fig. 3 The top row shows a successful gas fracturing test for sample no. 3 . On the surface of the sample, where powder gases left the test system, a small fracture system is macroscopically visible. The bottom row shows an unsuccessful attempt to fracture sample no. 5, where the pressure as a result of imperfections of the carbon sample did not propagate with a drilled channel imitating perforation, and the edge between the sample and the casing

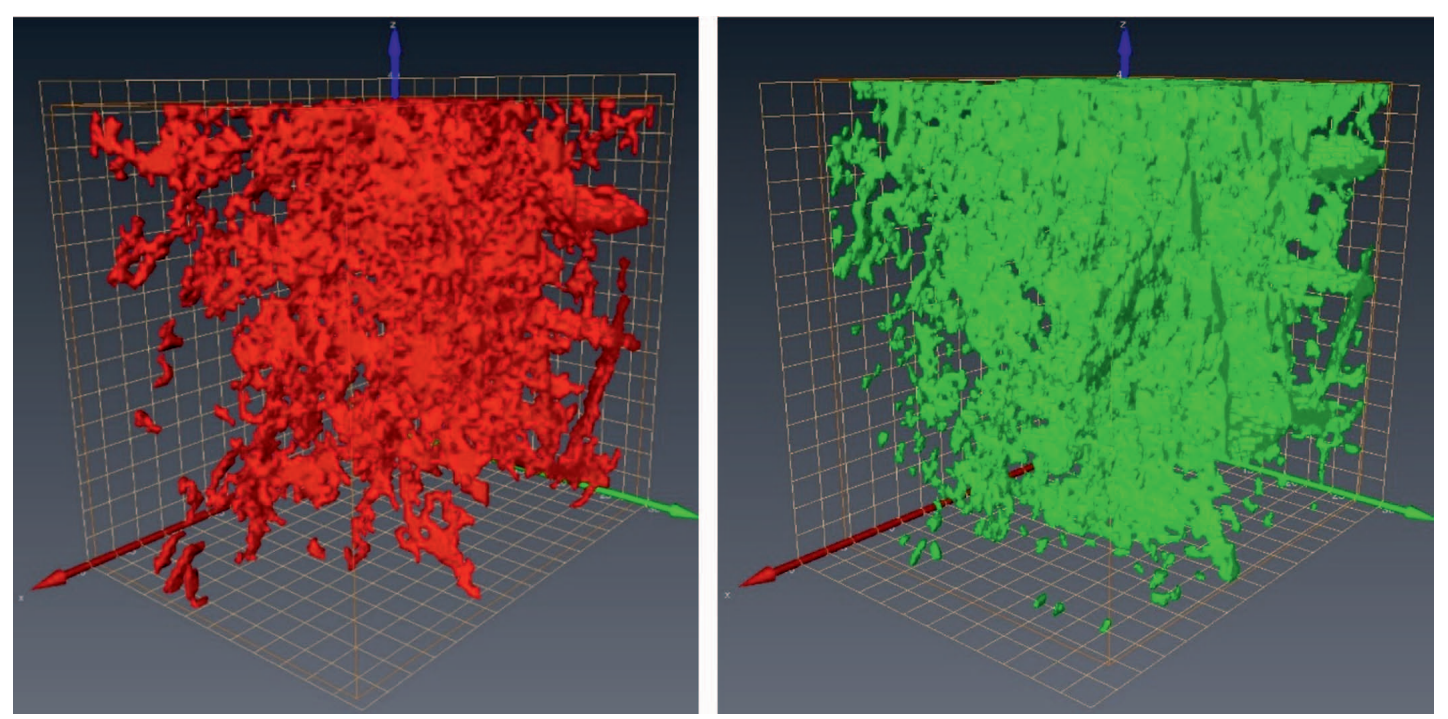

Rys. 4. Obrazy spękań w próbce węgla kamiennego nr 4 przed i po szczelinowaniu gazowym. Obrazy powstały w wyniku rekonstrukcji tomogramów komputerowych

Fig. 4. Images of fractures in hard coal sample no. 4 before and after gas fracturing. The images were created as a result of reconstructing the computer tomograms

W efekcie rekonstrukcji tomogramów uzyskano również dane liczbowe na temat objętości szczelin w każdej próbce węgla kamiennego przed i po próbach na poligonie doświadczalnym (tab. 1).

Dane tabelaryczne zestawiono ze sobą na wykresie, pomijając próbki, w których zabieg szczelinowania gazowego się nie powiódł. Obliczono współczynnik korelacji dla próbek węgla $1-7$, który wyniósł $-0,32$, co oznacza, że korelacja jest słaba ujemna, więc brak jest zależności pomiędzy ciśnieniem maksymalnym w układzie badawczym a uzyskanym przyrostem szczelin w badanych próbkach skały.

Przyrost objętości szczelin w próbkach węgla jest bardzo zróżnicowany i wynosi od 9,3\% do 332,5\% w porównaniu z objętością spękań istniejących w próbce. 
Tabela 1. Dane uzyskane po próbach ciśnieniowych

Table 1. Input data after pressure tests

\begin{tabular}{|c|c|c|c|c|c|}
\hline \multirow{2}{*}{ Nr próby } & $\begin{array}{c}\text { Masa paliwa } \\
\text { MPH }\end{array}$ & $\begin{array}{c}\text { Pierwotna objętość } \\
\text { szczelin w próbce }\end{array}$ & $\begin{array}{c}\text { Wtórna objętość } \\
\text { szczelin w próbce }\end{array}$ & $\begin{array}{c}\text { Przyrost objętości } \\
\text { szczelin w próbce }\end{array}$ & $\begin{array}{c}\text { Ciśnienie maksymalne } \\
\text { w ukladzie }\end{array}$ \\
\cline { 2 - 6 } & {$[\mathbf{g}]$} & {$[\%]$} & {$[\%]$} & {$[\%]$} & 5,8 \\
\hline \hline 1 & 20 & 3,00 & 8,29 & 176,3 & 1,58 \\
\hline 2 & 20 & 6,70 & 7,32 & 9,3 & 10,15 \\
\hline 3 & 25 & 5,48 & 23,70 & 332,5 & 5,85 \\
\hline 4 & 25 & 6,42 & 11,72 & 82,6 & 14,45 \\
\hline 5 & 30 & 1,39 & 2,00 & 43,9 & 20,68 \\
\hline 6 & 45 & 3,17 & 3.77 & 18,9 & 35,72 \\
\hline 7 & 54 & 2,27 & 2,58 & 13,7 & 2,35 \\
\hline 8 & 29 & 8,10 & - & - & 22,65 \\
\hline 9 & 46 & 2,36 & - & - & 3,90 \\
\hline 10 & 35 & 1,80 & - & - & \\
\hline
\end{tabular}

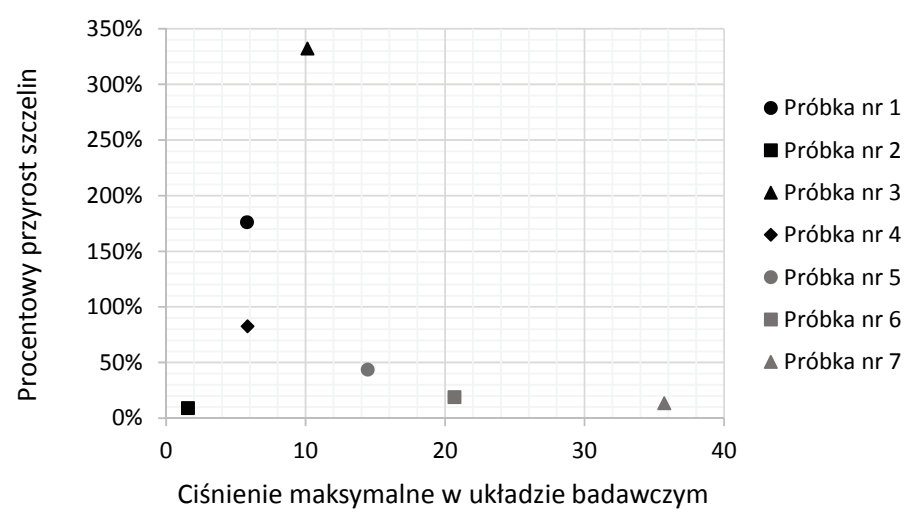

Rys. 5. Wykres zmian ciśnienia maksymalnego w układzie badawczym do procentowego przyrostu szczelin podczas każdej z udanych prób szczelinowania gazowego

Fig. 5. Graph of maximum pressure changes in the test system to the percentage increase in fractures during each successful gas fracturing test

Zaobserwowano, że dla próbek nr 1, 3, 4 i 5 w przedziale ciśnień maksymalnych od 5,8 MPa do 14,45 MPa przyrost szczelin w badanych skałach jest największy i wynosi od $43,9 \%$ do $332,5 \%$, przy czym maksymalną wartość przyrostu szczelin osiągnięto przy ciśnieniu 10,15 MPa w próbce $\mathrm{nr} 3$. W próbce nr 2 ciśnienie maksymalne wyniosło $1,58 \mathrm{MPa}$ i spowodowało przyrost szczelin na poziomie 9,3\%. Zbyt duże ciśnienie również nie wpływa korzystnie na przyrost szczelin w węglach. W próbkach nr 6 i 7 ciśnienie maksymalne wynosiło 20,68 MPa oraz 35,72 MPa, a uzyskany przyrost szczelin znalazł się na poziomie $18,9 \%$ i $13,7 \%$.

W próbkach nr 1 i 4 ciśnienie szczelinowania skały było zbliżone do siebie, kolejno 5,8 MPa oraz 5,85 MPa, a przyrost szczelin w tych próbkach różny - 176,3\% i 82,6\%. Na tej podstawie stwierdzono, że na podatność węgli na szczelinowanie gazowe mają również wpływ ich indywidualne cechy strukturalne.

\section{Podsumowanie}

Przedstawiono próbę szczelinowania gazowego z wykorzystaniem materiałów wysokoenergetycznych w laboratoryjnym silniku rakietowym dla 10 próbek węgla kamiennego.

Celem badania była ocena możliwości szczelinowania gazowego węgli. Próbki przed badaniem odpowiednio przygotowano: $\mathrm{z}$ większych brył wyrdzeniowano mniejsze walce i wklejono je w specjalne obudowy umożliwiające przeprowadzenie doświadczenia w układzie laboratoryjnego silnika rakietowego. Podczas każdej z prób szczelinowania rejestrowano ciśnienie maksymalne w układzie badawczym. Próbki węgla przeskanowano tomografem komputerowym przed i po badaniach na poligonie doświadczalnym, a następnie zrekonstruowano uzyskane tomogramy na obrazy 3D i dane liczbowe dotyczące sieci spękań w skałach.

Zabieg szczelinowania w próbkach nr 8, 9 i 10 nie powiódł się. Było to spowodowane niejednorodnością w badanych próbkach węgla. Ciśnienie produktów spalania propelantów propagowało krawędzią pomiędzy węglem a stalową obudową, przez co nie następowało szczelinowanie węgla.

W pozostałych 7 próbkach węgla kamiennego produkty spalania propelantów pierwotnie propagowały nawierconym kanałem perforacyjnym, poszerzając go, a następnie szczelinowały próbkę poprzez istniejącą sieć spękań, będącą punktami osłabienia skały. Mimo że otrzymane szczeliny nie są modelowymi spękaniami, to zaobserwowano ich przyrost w badanych walcach węglowych. 
Nie uzyskano korelacji pomiędzy ciśnieniem maksymalnym osiągniętym w układzie badawczym a przyrostem szczelin w skałach. Przyrost szczelin w próbkach skały jest bardzo zróżnicowany: od 9,3\% do 332,5\%. Największy przyrost szczelin osiągnięto dla ciśnień maksymalnych od 5,8 MPa do 14,45 MPa w próbkach 1, 3, 4 i 5. Przyrost szczelin w tych walcach węglowych wyniósł od 43,9\% do 332,5\%, przy czym maksymalny wynik osiągnięto przy ciśnieniu 10,15 MPa. W przypadku pozostałych próbek $(2,6,7)$ ciśnienie maksymalne w układzie było zbyt niskie (1,58 MPa) lub zbyt wysokie (20,68 MPa i 35,72 MPa), przez co rezultaty szczelinowania są na poziomie od $9,3 \%$ do $18,9 \%$.

Porównując próbki nr 1 i 4, w przypadku których ciśnienie szczelinowania było bardzo podobne i wyniosło $5,8 \mathrm{MPa}$ oraz 5,85 MPa, zaobserwowano różny przyrost szczelin, który równał się $176,3 \%$ i $82,4 \%$. Na tej podstawie stwierdzono, że duży wpływ na przyrost szczelin w węglach podczas zabiegu szczelinowania gazowego mają ich indywidualne cechy strukturalne.

W toku badań dowiedziono, że szczelinowanie gazowe materiałami wysokoenergetycznymi jest w stanie wytworzyć wtórną sieć spękań w badanych skałach, przez co może okazać się skuteczne do pozyskiwania metanu z pokładów węgla.

Artykuł został opracowany na podstawie prac statutowych pt.: Zastosowanie rentgenowskiej mikrotomografii komputerowej do oceny efektów szczelinowania gazowego w węglu kamiennym w skali laboratoryjnej - praca INiG - PIB na zlecenie MNiSW; nr zlecenia 0022/ST/2017, nr archiwalny DK-4100-9/2017, oraz Zastosowanie materiatów wysokoenergetycznych do szczelinowania wegla kamiennego $w$ skali laboratoryjnej- praca INiG - PIB na zlecenie MNiSW; nr 0035/ST/2018, nr archiwalny DK-4100-0035/2018.

\section{Literatura}

Gonet A., Nagy S., Rybicki C., Siemek J., Stryczek S., Wiśniowski R., 2010. Technologia wydobycia metanu z pokładów węgla (CBM). Górnictwo i Geologia, 5(3): 5-25.

Habera Ł., Frodyma A., Hebda K., Koślik P., 2019. Badania temperatury spalania propelantów w układach z przybitką cieczy. Nafta-Gaz, 9: 556-561. DOI: 10.18668/NG.2019.09.04.

Habera Ł., Frodyma A., Koślik P., Wilk Z., 2014. Nowoczesne urządzenia perforująco-szczelinujące - koncepcja i badania poligonowe. Nafta-Gaz, 5: 301-306.

Hadro J., 2010. Strategia poszukiwań gazu ziemnego w łupkach. Przeglad Geologiczny, 58: 250-258.

Hadro J., Wójcik I., 2013. Metan pokładów węgla - zasoby i eksploatacja. Przegląd Geologiczny, 61: 404-410.
Hebda K., Habera Ł., Dohnalik M., Koślik P., Hadzik J., 2018a. Ocena dynamiki spalania propelantów w środowisku węgla kamiennego. Nafta-Gaz, 1: 22-28. DOI: 10.18668/NG.2018.01.02.

Hebda K., Habera Ł., Frodyma A., Koślik P., 2019. The study of gas fracturing on hard coal samples using propellants. Nafta-Gaz, 6: 350-355. DOI: 10.18668/NG.2019.06.06.

Hebda K., Habera Ł., Frodyma A., Wilk Z., Koślik P., Hadzik J., 2018b. Badanie charakterystyki spalania materiałów wysokoenergetycznych w laboratoryjnym silniku rakietowym przystosowanym do badań próbek węgla kamiennego. Przemyst Chemiczny, 7(97): 1064-1067. DOI: 10.15199/62.2018.7.6.

Krzystolik P., Skiba J., 2009. Gospodarcze wykorzystanie metanu z pokładów węgla w warunkach polskich. Polityka Energetyczna, 12(2/2): 319-332.

Kwarciński J., Hadro J., 2008. Metan z pokładów węgla na obszarze Górnośląskiego Zagłębia Węglowego. Przegląd Geologiczny, 56: 486-490.

Poprawa P., 2010. System węglowodorowy z gazem ziemnym w łupkach - północnoamerykańskie doświadczenia i europejskie perspektywy. Przegląd Geologiczny, 58: 216-225.

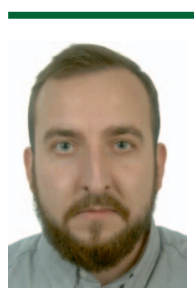

Mgr inż. Kamil Hebda

Specjalista inżynieryjno-techniczny w Zakładzie Techniki Strzelniczej

Instytut Nafty i Gazu - Państwowy Instytut Badawczy ul. Lubicz $25 \mathrm{~A}$

31-503 Kraków

E-mail: kamil.hebda@inig.pl

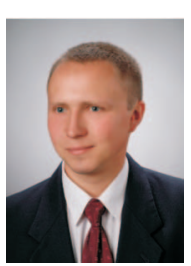

Dr inż. Łukasz HABERA

Adiunkt w Zakładzie Techniki Strzelniczej

Instytut Nafty i Gazu - Państwowy Instytut Badawczy ul. Lubicz $25 \mathrm{~A}$

31-503 Kraków

E-mail: lukasz.habera@inig.pl

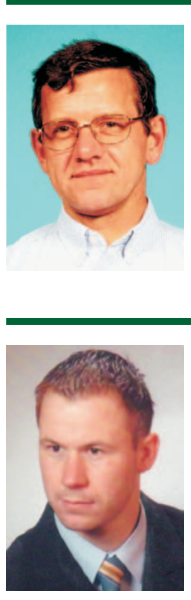

Mgr inż. Antoni FRODYMA

Główny specjalista inżynieryjno-techniczny;

kierownik Zakładu Techniki Strzelniczej

Instytut Nafty i Gazu - Państwowy Instytut Badawczy ul. Lubicz 25 A

31-503 Kraków

E-mail: antoni.frodyma@inig.pl

Mgr inż. Piotr KOŚLIK

Specjalista badawczo-techniczny w Instytucie

Przemysłu Organicznego w Warszawie

Oddział w Krupskim Młynie.

ul. Zawadzkiego 1

42-693 Krupski Młyn

E-mail:piotr.koslik@ipo.waw.pl 